\title{
The Development of Audio-Visual Media for News Text Learning at SMP Negeri 2 Lawang Kidul Tanjung Enim
}

\author{
Desta Lingga Sari \\ SMK PGRI Muaraenim \\ destasinulingga@gmail.com \\ Missriani \\ SMK PGRI Muaraenim \\ Missriani05@yahoo.com \\ Arif Ardiasnyah \\ SMK PGRI Muaraenim \\ Arifacong@yahoo.com
}

Corresponding author: Desta Lingga Sari (destasinulingga@gmail.com)

\begin{abstract}
This study aims to determine and identify the development of audio-visual media for news text learning at SMP Negeri 2 Lawang Kidul Tanjung Enim, to find out and identify the results of the validation of audio-visual media for news texts learning for students of SMP Negeri 2 Lawang Kidul Tanjung Enim, and to find out and identify the results of news text learning for students of SMP Negeri 2 Lawang Kidul Tanjung Enim after the application of audio-visual media. The design of audio-visual media for learning news text for students of SMP Negeri 2 Lawang Kidul Tanjung Enim which has been accepted by the experts is feasible to be tested. This study used research and development methods. The research and development steps consist of 10 stages which includes problem identification, data collection, product design (Initial Draft), expert validation, design improvement, small group trials, product revisions, large group trials, product revisions, and final production The results of the validation of media experts, material experts and language experts on the development of audio-visual media products for learning news texts for students at the State Junior High School 2 Lawang Kidul Tanjung Enim are in the very good category. Applied audio-visual media has increased the criteria for being very effective.
\end{abstract}

Keywords: Audio-visual media development; news text; learning

\section{A. Introduction}

School education is formal education which serves to help students follow the learning process. Wena (2014:160) stated that learning is an effort to teach students to learn. Learning activities will involve students to learn in an effective and efficient way. Houtman (2017:82) explained that the succes of the education is influenced by many factors. In its activities, learning is not a transfer of knowledge from educators to students, but the involvement of students in connecting with their life is very high. Students should know the meaning of learning and use the knowledge and skills they acquire to solve problems in life.

Learning Indonesian is a communicative interaction process that emphasizes aspects of language. One of the functions of learning Indonesian in schools is as a national language, which is a tool that allows the integration of various ethnic groups with different socio- 
cultural backgrounds and regional languages into one unified national unity (Finoza, 2009:234). Therefore, learning Indonesian must be mastered by students and it is expected that no student will experience learning difficulties in learning Indonesian.

Writing activity is a form of manifestation of language abilities and skills that are most recently mastered after other abilities, even it is more difficult to master by native speakers. Writing is also useful for speaking (syafryadin, et al. 2019). This is due to the ability to write requires mastery of various linguistic elements and other elements outside of the language itself (Rahmawati, et al. 2019; Syafryadin, 2020; Nurgiyantoro, 2020:270; Febriani, 2020). Surely, writing is still in relation to reading because by reading, people can read (Martina, et. al. 2020; Syafrizal, et al. 2020).

The problem that is often complained about in learning Indonesian at school is the low ability to write news. Based on the results of observations made by the researcher at SMP Negeri 2 Lawang Kidul Tanjung Enim, it was found that the elements of the news written by students were incomplete because there were no $5 \mathrm{~W}+1 \mathrm{H}$ elements. The teaching and learning process carried out by the teacher is also monotonous since they used the lecture and assignment method only, as a result students feel bored when learning takes place. In addition, the media used by the teacher in learning to write news texts did not exist because there were no facilities. The school already has learning media such as the Licquid Crystal Display (LCD). The use of instructional media is very important in the teaching and learning process. All of these problems can be overcome when there is a teacher who is creative, innovative, and must be able to develop learning media, especially audio-visual media.

Based on the results of preliminary observations that the researcher has conducted at SMP Negeri 2 Lawang Kidul Tanjung Enim, it was found that the Indonesian language learning process has used varied learning models. However, the learning media were not used optimally. The availability of supporting facilities and infrastructure such as Liquid Crystal Display (LCD) projectors, lapto ps, and audio should be used as learning media.

Therefore, audio-visual media is not applied during the Indonesian language teaching and learning process. The results of observations made by the researcher also stated that student activities in participating in learning were less active, so alternative ways were needed in order to increase these activities. One of which is to develop the audio-visual media.

The phenomenon occured is that the learning result of news texts writing at SMP Negeri 2 Lawang Kidul Tanjung Enim is not optimal. Based on the results of preliminary observations made by the researcher at SMP Negeri 2 Lawang Kidul Tanjung Enim, it was found that $57 \%$ of students were unable to identify and study the elements, structures, and language of the text. Therefore, the results of writing news texts were still low and did not reach the minimum completeness criteria set by the school, which is 70 , while $43 \%$ have reached the minimum completeness criteria. Therefore, learning to write news texts in Indonesian still needs to be improved. With the development of instructional media, it is expected that it can encourage the improvement of competencies in the news text writing .

The results of observations made by the researcher also stated that student activities in participating in learning were less active. In the learning process students are passive, do not pay attention, are embarrassed to ask questions, do not record material in the learning process, and only accept what the teacher says. In addition, learning activities are more teachercentered or one-way communication, which is from teacher to student.

The implementation of learning is also more on mastering concepts, and does not make use of learning media. In fact, SMP Negeri 2 Lawang Kidul Tanjung Enim has facilities 
such as a Liquid Crystal Display (LCD) projector, laptop, and audio for learning activities. However, while in the learning process these tools are not used. Therefore, audio-visual media is not applied during the Indonesian language teaching and learning process.Sudjana dan Rivai (2010:2) suggest that there are various reasons regarding the benefits of teaching media in the student learning process, that is teaching will attract more students' attention so that it can foster learning motivation, teaching materials will be clearer, and teaching methods will be more varied, not solely verbal communication through wording by the teacher, so that students are not bored and teachers do not run out of energy, especially if the teacher teaches for every class hour.

Learning by utilizing the media will make it easier for students to grasp the concepts that are tethered to their memory. The role of media in the learning process is very important to support the achievement of learning objectives. One form of media that utilizes technology is audio-visual media.

The media functions as a medium or channel of communication in receiving message content involving the sense of sight, elements of moving images and the sense of hearing or sound elements. Therefore, it is necessary to develop audio-visual media for learning activities.

\section{B. Research Methodology}

This study aims to determine and identify the development of audio-visual media for news text learning at SMP Negeri 2 Lawang Kidul Tanjung Enim, to find out and identify the results of the validation of audio-visual media for news texts learning for students of SMP Negeri 2 Lawang Kidul Tanjung Enim, and to find out and identify the results of news text learning for students of SMP Negeri 2 Lawang Kidul Tanjung Enim after the application of audio-visual media. This research was conducted at SMP Negeri 2 Lawang Kidul which is located at Kiemas street, No. 1, Simpang Mandala, Tj. Enim, Lawang Kidul, Muara Enim Regency, South Sumatra 31711.

This study used research and development methods. The research and development steps consist of 10 stages which includes problem identification, data collection, product design (Initial Draft), expert validation, design improvement, small group trials, product revisions, large group trials, product revisions, and final production (Sugiyono, 2012:149). Arikunto (2016:112) defined the population as the whole subject of the study. Thus, the population of this study were the students of class VIII at SMP Negeri 2 Lawang Kidul Tanjung Enim, totaling 215 people consisting of 6 classes. The sample is part of the number and characteristics possessed by the population. Sampling from a population has its own rules and techniques.

Using the right technique allows researchers to extract reliable data. Therefore, the provisions in drawing samples are important in any scientific research activity. Sugiyono (2012: 91) stated that the sample is part of the number and characteristics of the population. According to Margono (2014: 121) the sample is part of the population. According to Arikunto (2016: 134) the sample is part of the object and representative being studied. The sampling technique used by the researcher was cluster random sampling, that is, the sample selection was not based on rank. Samples were taken by lottery as much as 1 class out of 6 classes. Based on the results of the lottery, a sample of class VIII was obtained, totaling 36 students. 
The data collection techniques in this study were documentation, questionnaire, and test. The data obtained through the questionnaire were then analyzed using a Likert scale to obtain opinions, appreciation and perceptions of experts and students after the application of audio-visual media. The categories used are: very good, good, enough, not good, very bad.

The form of the test used in this research is a filling test by providing reading material then the students find the $5 \mathrm{~W}+1 \mathrm{H}$ concept on the news. To assess students' news texts in this study, models or criteria were used. Data analysis technique is a method used to manage data collected and classified according to research objectives.

\section{Result and Discussion 1. Results}

The development model in this research consists of 10 stages which include problem identification, data collection, product design, expert validation, design improvement, small group trials, product revisions, large group trials, product revisions, and final production. The following is a brief description of each stage.

\section{a. Identification of problems}

This stage is the initial stage in development research. Problem identification is a needs analysis that aims to find problems. The results of the observations carried out by the researcher at SMP Negeri 2 Lawang Kidul Tanjung Enim found that the implementation of news text learning was more on mastery of concepts, and did not utilize learning media. Learning facilities at SMP Negeri 2 Lawang Kidul Tanjung Enim are also adequate, it has facilities such as Liquid Crystal Display (LCD) projectors, laptops, and audio that can be used for news text learning activities. News text learning activities do not use audio-visual media, but only images or Indonesian language textbooks are used.

\section{b. Need Analysis Results}

According to the teacher's response at SMP Negeri 2 Lawang Kidul Tanjung Enim, media can be used and help for news text learning activities. Teachers at SMP Negeri 2 Lawang Kidul Tanjung Enim only use image media in learning news texts, and they do not use audio-visual media. The reason given by the teacher for not using audio-visual media was that it was difficult to make products for news text media. This is due to the lack of understanding of the programs in making the audio-visual media. In addition, the teacher also thought that with the application of audio-visual media for learning news texts, learning will certainly be more interesting and can increase student motivation in learning. The teacher also stated that there needs to be a development for learning news texts for audio-visual media. The Indonesian teacher at SMP Negeri 2 Lawang Kidul Tanjung Enim also stated that it is highly recommended or recommende for the researcher to develop audio-visual media for learning news text.

\section{c. Product Selection Draft Description}

In making this development product application, various programs or applications are needed including Swish max4, Cute Video Cutter, VideoPad Video Editor, Ultra Video Joiner, Powerpoint, Any Video Converter Ultimate, Format Factory and Switch Sound File Converter. To be able to run this development program, a Macromedia Flash Player application is needed. Developed news text learning begins with opening the product or program that has been created. Next step, click the start button to continue the program. After that, before entering the material to be studied, an introductory video is needed to motivate students to participate in learning activities. This aims to make students more motivated and 
more focused in following the teaching and learning process. After being given motivation, a material slide is made with 4 choices of Basic Competencies which include: KD 3.1, KD 4.1, KD 3.2, and KD 4.2.

\section{d. Design Validation}

The next step is to validate the design. Design validation is a product design appraisal process that is carried out by providing an assessment based on rational thinking, without field testing. Expert validation is carried out with 3 experts, namely media experts, material experts, and linguists. Aspects that are measured by media expert validation include: audiovisual media instructions, objectives in audio-visual media, presentation, appropriateness, clarity, precise accuracy, display or images of audio-visual media, audio-visual sound, and use of symbols or icons in audio-visual media.

Furthermore, for material expert validation, the measured indicator material includes: instructions for using audio-visual media, clarity of core competences and basic competencies, relevance of core competencies and basic competencies, clarity of learning objectives formulation, clarity of news text material, relevance of material with learning objectives, truth of material substance and text, the relevance of examples with explanations, the design of the presentation of the material, giving motivation and attraction (color, images, and video), clarity of audio-visual media, coverage of news text material, depth of news text material, and suitability of material with the development of students.

For the linguists, the indicators measured include: spelling accuracy according to the spelling of the applicable language, clarity of news text in audio-visual media, language accuracy in news text in audio-visual media, presentation of news text in audio-visual media, suitability of news text language with target (students), legibility (editorial and punctuation), accuracy in using grammar (language), the accuracy of the news text selection, the accuracy of the sentences/language used, the consistency of the language (the language used does not use the locally applicable language), the use of language is in accordance with the characteristics of students, the clarity of the language of the audio-visual media instructions, the accuracy of the use of language used does not contain words/expressions that can offend teachers and students), the accuracy of cohesion in the sentence in the news text, and the accuracy of coherence between paragraphs in the news text.

\section{Discussion}

Based on the research results, it was found that this study used the research and development method consisting of various stages. The initial stage is to identify the problem for the needs analysis. Based on the results of the research it was found that the implementation of learning news texts that had been carried out at SMP Negeri 2 Lawang Kidul Tanjung Enim was more on mastery of concepts, and did not utilize learning media. The learning facilities at SMP Negeri 2 Lawang Kidul Tanjung Enim are also adequate, such as the availability of Liquid Crystal Display (LCD) projector, laptop, and audio that can be used for news text learning activities. News text learning activities do not use audio-visual media, but only images or Indonesian language textbooks are used.

Based on the results of preliminary observations made by the researcher at SMP Negeri 2 Lawang Kidul Tanjung Enim, it was found that $57 \%$ of students had not been able to identify and study the elements, structures, and language of the text. According to the teacher's response at SMP Negeri 2 Lawang Kidul Tanjung Enim, the media can be used and helps for news text learning activities. Teachers at SMP Negeri 2 Lawang Kidul Tanjung 
Enim only use image media in learning news texts, and they do not use audio-visual media. The reason given by the teacher for not using audio-visual media was that it was difficult to make products for news text media.

The next stage is the preparation of an initial draft of product selection. At this stage, the researcher determines three phases or three stages of learning, that is the introduction, core activities, and closing. After that, it is followed by the next step, which is to validate the design. Design validation was carried out by three experts, namely media experts, material experts, and language experts.

Based on the results of the evaluation or validation of media experts on the product development of an audio-visual learning model for learning news texts, a score of 4.54 was obtained. The media expert gave a suggestion: it was good, only need to add animations appropriate to the junior high school level. The suggestions given have also been corrected. Thus, the conclusion of the media expert is worthy of testing with revision

Based on the results of the validation evaluation by material experts, a score of 4.2 was obtained. This average is categorized as very good validity level. Material experts provided advice, that overall the material presented is in accordance with the competencies and indicators to be achieved, there are only slight deficiencies in information and writing errors in the media text. The suggestions put forward by the experts have been corrected. Thus, the conclusions given for the validation of material experts are worthy of testing with revision.

Furthermore, the researcher validated with linguists. Based on the results of the validation evaluation, the score 4.86 was obtained. This average is categorized as very good validity level. The linguist suggested that inaccurate words should be corrected, and that overall the directions were clear and that research should be continued. The linguist's advice has been corrected. Thus, the conclusions given for linguist validation are worthy of testing with revision.

After expert validation, the next step is to improve the product design. Product design improvements are carried out based on expert opinion. The improvement aims to make the product more attractive. In addition, product improvements are also made to make the product better. Product improvements according to the advice of individual experts have also been improved.

After revising the product design, the next step for research and development is to test the product on a small scale. Trial is carried out to determine the effectiveness of the product being developed. Before being given lesson using audio-visual media for learning news texts, the total score of news texts was 190, with an average of 190. After applying audio-visual media for learning news texts, the total score of news texts increased to 308, with an average of 30,8 . The increase that occurred was $308-190=118$ with an increase in the average number of $30,8-19=11,8$. The average normalized gain is 0,702 which is included in the high category.

In addition to scoring, an assessment is carried out based on the learning outcome criteria. From this score, then it was converted into value. Based on the results of the calculation, the average value of the news text pretest on the small group product trial was 52,78 which was included in the low category, while the posttest value of news text on the smallgroup product trial was 85,56 which was included in the very good category. Thus, it can be concluded that the development of news text audio-visual media for smallgroup participants has increased. 
After that, hypothesis testing was carried out which aims to determine the increase in news text after the application of audio-visual media. Tests were carried out using SPSS version 22.00 for Windows and $t$ test was performed. Based on the results of the calculation, it was found that the average (mean) pre-test score was 52,78 while the average post-test score was 85,56.

Thus, the posttest mean is higher than the pre-test. In addition, the results of hypothesis testing obtained a significant value of $0.00<0.05$, while the $t$ test calculation obtained a value of $\mathrm{t}_{\text {count }}=20,557>\mathrm{t}_{\text {table }}=1,833113$ at the level of $5 \%$ or 0,05 . The calculation of SPSS results can be seen in the attachment. Based on the decision making criteria, it can be concluded that the development of audio-visual media can improve the results of the news text for small group participants.

Based on the results of the small group product trial questionnaire answers, the number of questionnaire answers was 323 with an average of 32,3 , while the average number was 46,14 with an average of 4,61. Thus, the development of audio-visual media for learning news text based on the results of the small group product trial questionnaire is included in the very good category.

After conducting product trials on the smallgroup the next stage is testing the use of the developed product. This trial was carried out on a research sample of 25 participants which aims to determine the effectiveness of the product being developed and to obtain input to revise the final stage product. Based on the research results, it was found that before learning using audio-visual media for learning news text, the total score of the news text was 490, with an average of 19,60. After applying audio-visual media for learning news texts, the total score of news texts increased to 782 , with an average of 31,28 . The increase that occurred amounted to $31,28-19,60=11,68$ with an average of 0.71 which was included in the high or very effective category.

After that, to determine the significance of the increase, hypothesis testing was carried out. Tests were carried out using SPSS version 22.00 for Windows and a Paired Sample Test ( $t$ test) was performed. Based on the results of the study, it was found that the average pre-test score (pretest) was 54,44, while the average post-test score was 86,89 .

Thus, the average postest test is higher than the initial test. In addition, the results of hypothesis testing show that the significant value is $0.00<0.05$. In addition, from the test, it obtained the value of $\mathrm{t}_{\text {count }}$ is 26,864 while the $\mathrm{t}_{\text {table }}$ value with $\mathrm{df}=\mathrm{n}-1=25-1=24$ at the $5 \%$ level $(=0,05)$ the $t$ table value is 1,72 . Thus, the value of $t_{\text {count }}=26,864>t_{\text {table }}=1,72$. Based on the decision-making criteria, it can be concluded that the development of audiovisual media can improve the results of news texts for learning participants at SMP Negeri 2 Lawang Kidul Tanjung Enim.

From the results of the small group product trial questionnaire answers above, it was found that the number of questionnaire answers was 688 with an average of 31,27, while the mean number was 98 with an average of 4,47. Thus, the development of audio-visual media for learning news text based on the results of the small group product trial questionnaire is included in the very good category.

Based on the results of the comments of the small group sample and the trial use, it was found that the products developed made students more enthusiastic in learning. Learning activities using media or development products are paying attention to the explanation of the media displayed. Students also like the developed media. The developed product helps 
students to be active in paying attention to learning and to participate actively in solving problems that exist in the development product.

The results of this study prove that the development of audio-visual media can improve the learning of news texts for students of SMP Negeri 2 Lawang Kidul Tanjung Enim. Thus, audio-visual media make a good contribution in learning news texts.

Arsyad (2011: 4) explained that the advantage of using audio-visual media is that the teaching material will have a clearer meaning so that it can be better understood by students, and allows students to master the teaching goals better. In addition, teaching will be more varied, not merely verbal communication through words spoken by the trainer. so that students do not get bored and coaches do not run out of energy. In addition, in learning activities, participants or students do not only listen to the trainer's explanation, but also carry out observation activities, conduct demonstrations, and better understand what the trainer says. Learning will also attract students' attention so that it can foster learning motivation. In addition, learning is captured faster and the duration of tamping information is longer because it involves two senses at the same time, thas is audio and visual, this is also related to the work function of the human brain.

Audio-visual media that have been developed in this research have their own characteristics. One of them is that it is easy to use and can have basic competencies to be learned. In addition, another special characteristic is the sparkol video scribe application which is more important in writing specifically on the learning media that has been developed.

Audio-visual media for learning news text has various advantages, such follows.

1. Can increase student enthusiasm and motivation to learn.

2. The application of audio-visual media for learning news texts that has been developed is easy to understand by students.

3. With the development of a learning model using audio-visual media, it is easier for teachers to provide explanations and act only as facilitators so that students become more active.

4. Audio-visual media for learning news texts that have been developed can also improve learning outcomes in learning news texts.

Besides having advantages, audio-visual media for learning news texts using audiovisual media that have been developed certainly have shortcomings. The shortcomings of the learning model that have been developed are as follows.

1. The application of audio-visual media learning must have facilities and infrastructure that can present this learning such as having a laptop, projector, active speakers, and other electronic facilities.

2. This media or product developed must have various applications and special skills, so that it takes time in the manufacturing process.

3. This learning also takes a little longer, because before learning it must be presented repeatedly for students who do not understand the application of learning. 
Jadila: Journal of Development and Innovation in Lanquage and Literature Education

Publisher: Yayasan Karinosseff Muda Indonesia
E-ISSN: 2723-6900

Volume 1 Number 12020

Page : : $119-127$

\section{CONCLUSION}

Based on the results of the research that has been done, the following conclusions are obtained.

a. The design of audio-visual media for learning news text for students of SMP Negeri 2 Lawang Kidul Tanjung Enim which has been recommended by experts is worthy of being tested.

b. The results of the validation of media experts, material experts, and linguists on the development of audio-visual media products for learning news texts for students of SMP Negeri 2 Lawang Kidul Tanjung Enim are in the very good category.

c. The results of the news text of the students of Lawang Kidul State Junior High School 2 Tanjung Enim after the application of audio-visual media have increased with the criteria of being very effective.

\section{References}

Arikunto, S. (2016). Prosedur penelitian suatu pendekatan praktik. Jakarta: Rineka Cipta.

Arsyad, A. (2016). Media Pembelajaran. Jakarta: PT. Raja Grafindo Persada.

Febriani, R. B. Satinem., Nurnaningsih., Haryani., Syafryadin, Noermanzah.(2020). Conveying an author's intention to efl readers: The meaning of "The Road Not Taken" by Robert Frost. International Journal of Innovation, Creativity and Change (IJICC), 13(4), 172.

Finoza, L. (2009). Komposisi bahasa Indonesia. Jakarta: Diksi Insan Mulia

Houtman. (2017). Digitalisasi pembelajaran dan pembentukan karakter siswa berbasis kearifan lokal. Wahana Didaktika. 15(2), 79-98.

Margono, S. (2014). Metodelogi Penelitian Pendidikan. Jakarta: Rineka Cipta.

Martina, F., Syafryadin, S., \& Utama, J. A. (2020). The Practice of extensive reading among EFL learners in tertiary level. Yavana Bhasha: Journal of English Language Education, 3(2), 56-72.

Nurgiyantoro, B. (2010). Penilaian pembelajaran bahasa berbasis kompetensi. Yogyakarta: BPFE.

Rahmawati, I. N., Syafryadin, S., \& Widiastuti, R. (2019). Teaching narrative writing using Freaky Fables Game: An Experimentation. English Education: Jurnal Tadris Bahasa Inggris, 12(2), 147-155.

Sugiyono. (2012). Penelitian kuantitatif, Kualitatif, dan R\&D. Bandung: Alfabeta.

Syafryadin, H., \& Salniwati, A. R. A. P. Digital storytelling implementation for enhancing students' speaking ability in various text genres. International Journal of Recent Technology and Engineering (IJRTE). 8(4), 3147-3151.

Syafryadin, S. (2019). Contrastive Analysis of Discourse Representation In Indonesia Newspaper (KOMPAS) and English Newspaper Reports (Jakarta Post). ENGLISH FRANCA: Academic Journal of English Language and Education, 3(02), 109-124.

Wibowo, Y., Syafrizal, S., \& Syafryadin, S. (2020). An analysis of English teachers' strategies in teaching reading Comprehension. JALL (Journal of Applied Linguistics and Literacy), 4(1), 20-27.

Tarigan, Henry Guntur. (2008). Teknik pengajaran keterampilan berbahasa. Bandung: Angkasa.

Wena, M. (2014). Model Pembelajaran yang Inovatif Kontemporer. Malang. Bumi Aksara. 